\title{
ONLINE BIOLÓGIA ÓRA A KONYHÁBÓL
}

\section{Szerzők:}

Borsos Éva

Újvidéki Egyetem

(Szerbia)

\section{Lektorok:}

Ujfaludi László (Ph.D.,professor emeritus) Eszterházy Károly Egyetem

Borbélyné Bacsó Viktória (Ph.D.) Medgyessy Ferenc Gimnázium

és további két anonim lektor...

Szerző e-mail címe:

bborsoseva@gmail.com

\begin{abstract}
Absztrakt
Már lassan egy éve a fennálló vírus helyzet miatt a legtöbb országban, a legtöbb iskolában digitális formában zajlik az oktatás az iskolákban. Ez hatalmas kihívás elé állítja a tanítókat, tanárokat. Egyre nehezebb kreatívnak lenniük, érdekes digitális órákat tartani, új ismeretek szerzésére motiválni a tanulókat. A diákok számára már megszokott, „unalmas” a számítógép, laptop képernyője előtt ülni, figyelni és a tananyagra összpontosítani. Munkánkban bemutatunk néhány olyan kísérletet, megfigyelést, játékot, melyekkel érdekesebbé tehetők a digitális biológia órák. Minden alapanyag, hozzávaló megtalálható a tanulók otthonában, így könnyedén kipróbálhatók akár szülői segítség nélkül is és megvalósítható a felfedezésen, a tapasztalatszerzésen alapuló tanulás.
\end{abstract}

Kulcsszavak: biológiatanítás, játék, kísérlet, megfigyelés, online oktatás

Diszciplína: pedagógia

\begin{abstract}
ONLINE BIOLOGY CLASS FROM THE KITCHEN

The COVID-19 virus situation exists till one year and in the most countries the education is realised in online form in schools. This situation makes enormous challenge for teachers. More and more difficult for them to be creative, to hold interesting online classes, to motivate pupils for getting more knowledge. For pupils it is boring and used to sit in front of the monitor of laptop or computer, to pay attention and to concentrate. In this work some experiments, observation, game is presented. Using them the online biology classes can be make more interesting. Every row
\end{abstract}


material, ingredient can find in pupils' home so they can try them even without help of their parents. In this way the experience based active learning can be realise.

Keywords: teaching biology, game, experiment, observation, online education

Discipline: pedagogy

Borsos Éva (2021): Online biológia óra a konyhából. OxIPO - interdiszciplináris tudományos folyóirat, 2021/4, 41-49. doi: 10.35405/OXIPO.2021.4.41

A világjárvány az oktatást is gyökeresen megváltoztatta. A megszokott tantermi oktatást felváltotta az otthoni digitális tanítás. Ez próbára teszi nem csak a pedagógusokat, de a tanulókat is. A módszertanban alapelvként elfogadott tény, hogy az ismeretszerzés sikerének a kulcsa az oktatási módszerek, munkaformák, taneszközök változatos alkalmazása (Czékus, 2005). Erre a digitális oktatás során nem igazán van lehetőség.

\section{A taneszközök}

Taneszköznek nevezünk minden olyan tárgyat, amely felhasználható az oktatás folyamatában, elôsegíti az oktatás céljainak elérését (Czékus, 2013). A fenti definíció tágabb értelmezése szerint egyedül a pedagóguson múlik, hogy mit is alkalmaz az adott tanítási egység, ismeretanyag tanulási folyamatának megkönnyítésére szemléltető segédeszközként. A taneszközöket azóta alkalmazzák, mióta oktatás létezik.

Történelmi szempontból öt csoportba sorolhatjuk a taneszközöket (Czékus, 2005). Az első csoportba tartoznak azok, amelyek technikai eszköz nélkül elkészíthetôk és használhatók. Ide tartoznak például a taneszközként forgalmazott, előre nyomtatott képek, modellek stb.

A második generációt azok az eszközök alkotják, amelyek esetében az elkészítéshez szükség van technikai eszközre, de az alkalmazáshoz már nem. A második csoportba tartoznak például a tankönyvek, a fényképek stb.

A harmadik nemzedék azokat a taneszközöket foglalja magába, amelyek technikai segítséggel készülnek, és technikai hátteret igényel a használatuk is. Ebbe a csoportba tartoznak például a hang- és videófelvételek stb.

A negyedik kategóriába sorolt taneszközök funkciója már nem csak a szemléltetés, hanem a tanulás irányítása is. Példaként az oktatóprogramokat említhetjük meg.

A legkorszerűbb ötödik csoportba azok a taneszközök sorolhatók, amelyek interaktív kapcsolatban állnak a felhasználóval.

A biológia oktatás során alkalmazott taneszközöket két nagy csoportba tudjuk felosztani (Kriska és Karkus, 2015). Az 
egyik nagy csoportba tartozik az élő anyag vagy annak maradványai, a másikba pedig a nem élő anyag. Az első csoportba tartoznak például a preparátumok, a kitömött élőlények, herbáriumi gyüjtemény stb. A nem élő anyag kategóriába sorolt taneszközöket tovább csoportosíthatjuk az alapján, hogy melyik érzékszervünkkel érzékeljük. Ez alapján lehetnek akusztikus és vizuális szemléltető eszközök. Az akusztikus taneszközök közé tartoznak például a madárhangok. A vizuális taneszközöket további két osztályra bonthatjuk két- illetve háromdimenziós eszközök és ezen belül is megkülönböztetünk álló és mozgó taneszközöket. Napjainkban ehhez csatlakozott még a háromdimenziós virtuális szemléltetés is. A biológia oktatás során külön hangsúlyt kapnak a kísérletek és a természetben elvégzett megfigyelések (Kriska és Karkus, 2015). Az itt használt eszközök a taneszközök külön csoportját képezik.

Akármelyik taneszközt is választjuk a tanítási óra megtartásához, az alapvető módszertani elveket minden esetben be kell tartani. A tanítási folyamat sikerességében kulcsfontosságú már a megfelelő taneszköz kiválasztása is. Fontos, hogy segítse az adott tanítási egység hatékony elsajátítását és alkalmazkodjon a tanulók pszichofizikai fejlettségéhez. A taneszközök megválasztásának feltételeit a következő pontokkal írhatjuk le: célkitűzés, tartalom, eredményesség, a pedagógus lehetôségei, a pedagógus képzettsége, gyakorlati tényezők, szervezési formák és módszerek és nem utolsósorban a gazdasági tényezők (Vörös, 2011). A leglényegesebb azonban az, hogy ne vigyük túlzásba a taneszközök alkalmazását, és ne mindig ugyanazokat az eszközöket használjuk (Czékus és tsai, 2013).

E tanulmány fô célja az, hogy az alábbiakban bemutatott kísérletekkel, megfigyelésekkel és játékkal segítsünk a tanároknak még érdekesebbé tenni a digitális biológia órákat, a tanulóknak pedig megkönnyíteni a tanulás folyamatát.

\section{Gyakorlatok}

Az alábbiakban öt olyan kísérletet, megfigyelést, játékot mutatunk be, melyekkel változatossabbá tehetjük a tanulók számára a digitális biológia órákat, hiszen otthon maguk is könnyen, biztonságosan elvégezhetik ezeket. Az öt kísérlet a következő lesz:

1. DNS izolálás banánból

2. Klorofill izolálás spenótból vagy más zöld levélből

3. Keményítő kimutatása jód oldattal

4. Módosult szárak és gyökerek vizsgálata

5. „Melyik növény vagyok én?” játék

\section{DNS izolálás banánból}

A genetikai információ a legtöbb élőlényben, a DNS-molekulában, a génekben van kódolva (Pedryc, 2014). A DNSmolekula legnagyobb része a sejtmagban helyezkedik el, de megtalálható a mitokondriumokban és a kloroplasztiszokban is. Egyes vírusok kivételével a molekula szerkezete egy kettőshélix konformációt alkot, melyben két nukleotidszál fut pár- 
huzamosan, jobbmenetes spirálban (lásd: Pedryc, 2014). Ha a spirált gondolatban széttekerjük, akkor egy létrára hasonlító szerkezetet kapunk, melynek két fő szálát cukor-foszfát gerinc alkotja. Ehhez kapcsolódnak hidrogénkötéssel a hélix belseje felé forduló bázisok. A DNS-molekulát alkotó bázisok mindig párban állnak: adeninnel szemben mindig timint, citozinnal szemben pedig mindig guanint találunk a spirálban. A sejtosztódások alkalmával a DNS-molekulák speciális fehérjék az úgynevezett hisztonok segítségével kondenzálódnak és kromoszómákba rendeződnek. Egy kromoszómát egy DNSmolekula alkot. Ezt a DNS-molekula - fehérje elegyet tudjuk kiizolálni akár otthon a konyhában is.

Fontos megjegyezni, hogy a DNSmolekula méretéből adódóan a spirált és a bázisokat nem fogjuk látni a kísérlet végén, azok csak megfelelő mikroszkópos nagyítással figyelhetők meg.

Hozzávalók: egy kb. 3-4 cm nagyságú banán darab, 1 kiskanál szódabikarbóna, 1/2 kiskanál konyha só, $150 \mathrm{ml}$ desztillált víz, $300 \mathrm{ml} \mathrm{70 \% -os} \mathrm{alkohol.}$

Szükséges eszközök: $1 \mathrm{db}$ villa, $1 \mathrm{db}$ kis tál, 1 db kiskanál, 1 db mérőpohár, $1 \mathrm{db}$ tölcsér, $1 \mathrm{db}$ nedvestörlőkendő, $1 \mathrm{db}$ pohár, 1db fogpiszkáló.

Feladat: a banándarabot törjük össze villával egy kis tálkában. A masszához adjunk hozzá 1 kiskanál szódabikarbónát és fél kiskanál sót, keverjük össze egy kiskanál segítségével. A masszához öntsünk $150 \mathrm{ml}$ desztillált vizet. Ha nincs mérōpoharunk, akkor próbáljunk egy negyed- bögrényit hozzáönteni. Ha véletlenül nem lesz pontosan $150 \mathrm{ml}$ akkor is sikerülni fog a kísérlet. A kapott elegyet kevergetni kell 3 percig egy kiskanál segítségével. Az egészet hagyjuk állni 10 percig szobahőmérsékleten, az asztalon vagy a munkafelületen. Egy kisebb pohárba helyezzünk egy tölcsért és béleljük ki egy nedves törlőkendővel. A nedves törlőkendőn keresztül szűrjük át az elegyet a pohárba, kicsit meg is nyomkodhatjuk a kis „,csomagot”. Az alsó kicsöpögő folyadékra lesz szükségünk, a többit kidobhatjuk. A kapott folyadéknak becsüljük meg a mennyiségét és lassan adjunk hozzá nagyjából kétszeres térfogatú 70\%-os alkoholt. Még hatékonyabb lesz az izolálás, ha az alkoholt egy picit behűtjük a hűtőszekrényben. Ha jól dolgoztunk, akkor a folyadék felszínén fog úszkálni a kiizolált DNS-fehérje elegyünk, amelyet egy fogpiszkáló segítségével közelebbről is megvizsgálhatunk (1. ábra).

A kísérlet más könnyen pépesíthető növénnyel is elvégezhető: földieperrel, leforrázott paradicsommal, stb.

\section{1. ábra: Az izolált DNS-fehérje elegy az al-} koholos oldat tetején (fotó: a Szerzó)

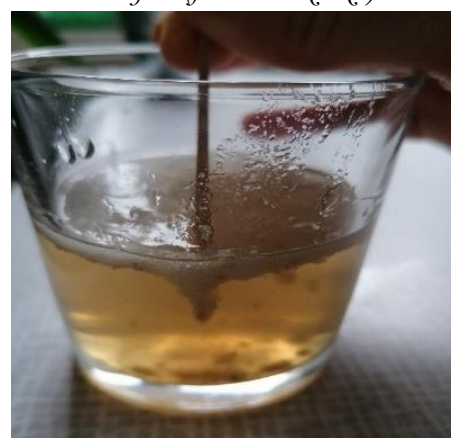




\section{Klorofill izolálás spenótból vagy más zöld levélböl}

A fotoszintézis fontossága az élővilág szempontjából, már régóta ismert. A folyamat során a zöld növények vagy más fotoszintézisre képes élőlények szén-dioxidból és vízből, a napfény energiájának megkötésével oxigént és szerves anyagot, cukrot állítanak elő. A folyamat számos reakciósorból áll és két alapvető részre, a fényszakaszra és a sötétszakaszra különíthető el. A folyamatban az egyik kulcsszerepet a kloroplasztiszokban - színtestekben - elhelyezkedő zöld színanyag, a klorofill tölti be.

A napfény energiájának jobb hasznosítása érdekében a klorofill két fajtája található meg a zöld növényekben: a 670 nmes tartományba eső fénysugarakat hasznosító klorofill-a és a $650 \mathrm{~nm}$-es tartományba eső fénysugarakat hasznosító klorofill-b (Ördög és Molnár, 2011). Ezt a zöld színanyagot tudjuk izolálni akár otthon is néhány könnyen darabolható zöld levélből.

Hozzávalók: 2-3 db spenót levél vagy más nagyobb levél, $100 \mathrm{ml} \mathrm{70 \% -os} \mathrm{alko-}$ hol.

Szükséges eszközök: gyorsforraló/ forró víz, 1 db kis tálka, 1 db mérôpohár, 1 $\mathrm{db}$ pohár, $1 \mathrm{db}$ villa, $1 \mathrm{db}$ tölcsér, $1 \mathrm{db}$ vizes törlőkendő (1 db iskolai fehér kréta).

Feladat: a leveleket forrázzuk le a gyorsforralóban felforralt vízzel egy kis tálkában. Várjunk nagyjából 5 percet, amíg kihűl és sérülés veszély nélkül tudunk vele tovább dolgozni. A leveleket tépkedjük szét apró darabkákra, akár kést is használ- hatunk. A széttépdesett leveleket egy villa segítségével pépesítjük. A kapott keverékhez öntsünk hozzá $100 \mathrm{ml}$ 70\%-os alkoholt és keverjük picit össze. Ha nincs mérőpoharunk, akkor szemmértékkel mérjük az alkoholt, a kísérletet nem fogjuk elrontani, csak kicsit hígabb klorofill oldatot fogunk kapni a kísérlet végén. A keveréket hagyjuk állni 5 percig szobahőmérsékleten, az asztalon vagy a munkafelületen. Egy kisebb pohárba helyezzünk egy tölcsért és béleljük ki egy nedves törlőkendővel. A nedves törlőkendőn keresztül szűrjük át az elegyet a pohárba, kicsit meg is nyomkodhatjuk a kis „csomagot”. $\mathrm{Az}$ alsó kicsöpögő folyadékra lesz szükségünk, a többit kidobhatjuk. A kapott folyadék a klorofill oldatunk alkoholban (2. ábra).

\section{2. ábra: Az izolált klorofill alkoholos oldata,} benne az iskolai fehér kréta (fotó: a Szerzö)

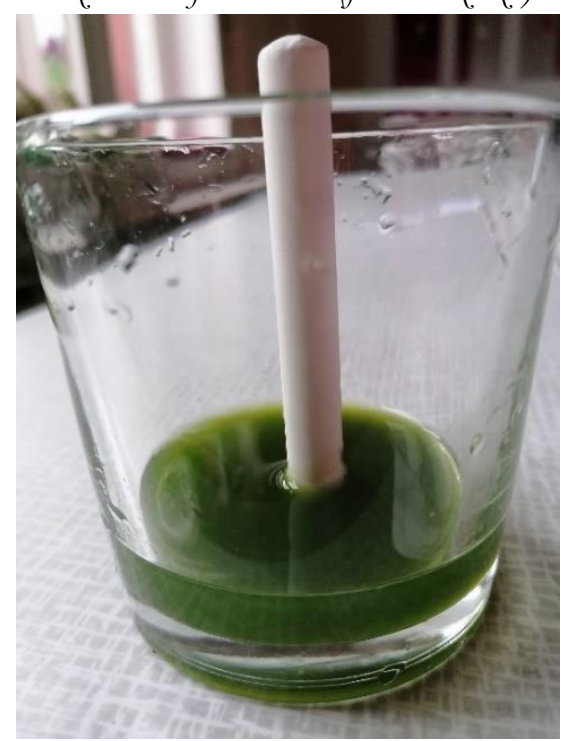


Ha van otthon egy fehér iskolai krétánk, akkor az oldatba függőlegesen beleállítva kromatográfiás elválasztást modellezhetünk. Ha ügyesek voltunk, akkor nagyjából fél óra elteltével a krétán megfigyelhető a két sáv: az elkülönített klorofill-a és klorofill-b.

A kísérlet akár fagyasztott spenóttal spenót brikett-tel -, vagy gyermekláncfü és menta keverékével is elvégezhető.

\section{Keményitö kimutatása jód oldattal}

A keményítő a poliszacharidok csoportjába tartozó szénhidrát. A növények keményítő formájában raktározzák a tápanyagot (Turcsányi és Turcsányiné Siller, 2005). A keményítő fehér színú, íztelen, szagtalan szilárd anyag. A keményítő jelenlétét jóddal tudjuk kimutatni. Ha a vizsgált minta tartalmaz keményítőt, akkor a jód barnás, narancssárgás színe, liláskékre, sötétkékre vált. A jelenség azzal magyarázható, hogy a jódmolekulák beépülnek a keményítő spirál szerkezetébe.

Hozzávalók: jód oldat, burgonya, keményítő tartalmú növények/anyagok.

Szükséges eszközök: 1 db reszelő

Feladat: Reszeljünk le egy darab burgonyát és cseppentjünk rá pár csepp jód oldatot. A barnás, narancssárgás színű jód oldat színe kékre, liláskék színűre fog változni (3. ábra). A feladatunk az, hogy keressünk még olyan növényeket, anyagokat a lakásban, konyhában, amelyek tartalmazhatnak keményítőt és végezzük el velük is a fent leírt kísérletet.
Fontos megjegyezni, hogy a jód oldattal lecsepegtetett növények, anyagok emberi fogyasztásra már nem alkalmasak, semmiféle körülmények között ne együk meg equket!

3. ábra: Keményitö kimutatása jód oldattal. A bal felsô" sarokban reszelt burgonya látható, a jobb felsö sarokban reszelt sárgarépa, alul közéepen pedig pékesütemény (fotó: a Szerzö)

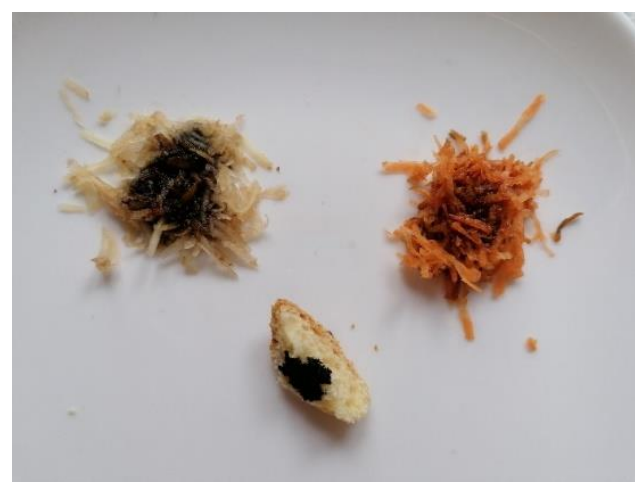

\section{Módosult szárak és gyökerek vizsgálata}

Módosultnak tekintjük azt a növényi szervet, amely az alapfeladatán kívül más feladatot is ellát vagy az alapfeladatától teljesen eltérő feladatot lát el a növényi szervezetben. Módosulhat a növény gyökere, szára vagy akár levele (Turcsányi és Turcsányiné Siller, 2005).

Feladat: keressünk otthonunkban olyan növényeket, melyeknek módosult szára, gyökere vagy levele van (4. ábra). 
4. ábra: A kaktusznak víztárolásra módosult pozsgás szára van (fotó: a Szerző́)

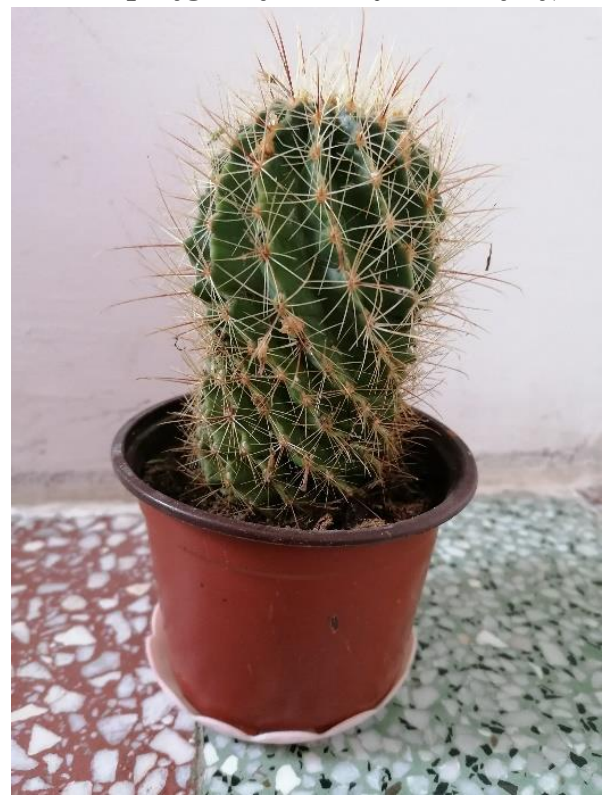

\section{5. „Melyik növény vagyok én?” játék}

Napjainkban a tanulók növényismerete nem igazán tekinthető még kielégítőnek sem (Borsos, 2018; Wagner, 2008). Egyértelmúen jellemzi ôket a növényi vakság (plant blindness), amely azt jelenti, hogy nem ismerik a közvetlen környezetükben élő növényeket és nem is akarják ezeket megismerni (Wandersee és Schlusser, 2001). A közel egy éve tartó digitális oktatás, a számítógépek előtt eltöltött egyre több idő csak rontottak ezen az állapoton. A tanulók szinte nem is tartózkodnak a természetben. A természetes környezetben zajló, tapasztalatszerzésre épülő aktív tanulás teljesen kimarad az életükből. Ezen okok miatt minden alkalmat meg kell ragadni, hogy bővítsük a növényekkel kapcsolatos ismereteiket. A „Melyik növény vagyok én?" elnevezésű játékot eredetileg a tantermen kívüli oktatás megkönnyítésére találták ki, de kiválóan alkalmazható a tanteremi oktatás során is (Borsos, 2018). A szókártyák módosításával otthon is izgalmas tanulási lehetőséget kínál. A játék lényege, hogy egy növény egyes szám első személyben mesél magáról és ki kell találni, hogy melyik növényrôl van szó. A szókártyák szövege illetve a játékban szereplő növények a tanulók tudásszintjének és az alkalmazott helyszínnek megfelelően módosíthatók, ily módon szinte bárhol, bárki játszhatja (Borsos, 2018). A játéknak verseny jelleget is adhatunk, ha például időkorlátot szabunk a növény nevének kitalálására. A feladatot nehezíthetjük azzal is, hogy olyan növény leírását is használjuk, amely nem található meg az adott helyszínen.

Feladat: a megadott szöveg alapján kitalálni melyik növény mesél magáról. Például: „Fontos zöldségnövény vagyok. Régóta ismernek és termesztenek. Magyar nevem a színemre utal, de lila, piros, sárga és fehér színű változatom is van. Első évben csak tőleveleket fejlesztek és zömök raktározó fögyökeret. A második évben jelenik meg a száram, amelyen fehér színű virágaim összetett ernyő virágzatot alkotnak. Termésem ikerkaszat. Sokféle vitamint tartalmazok. Szerintem a mai levesben is találkoztál velem (;) Melyik növény vagyok én?”

Megoldás: sárgarépa (Daucus carota lásd: 5. ábra). 
5. ábra: Sárgarépa, abogyan a tanulók a boltok polcain találkoznak vele (fotó: a Szerrố)

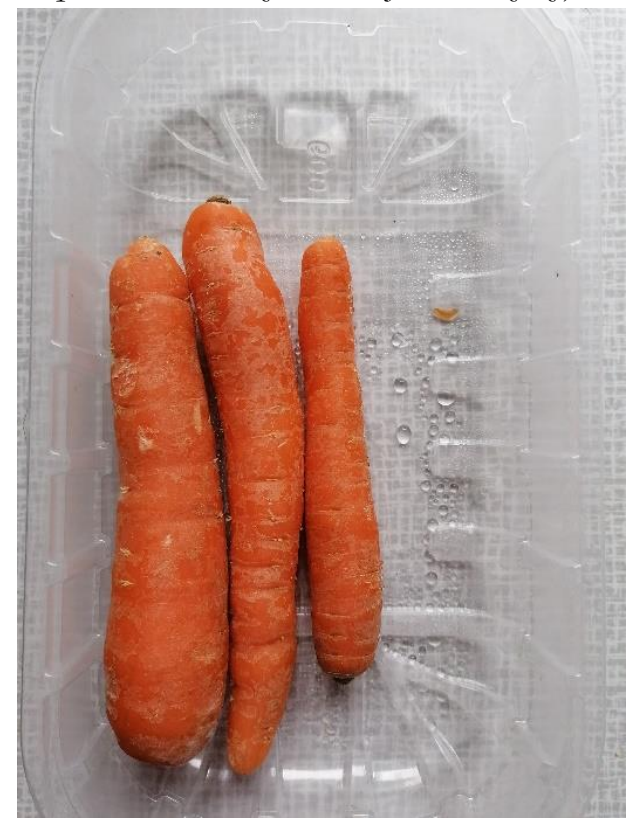

\section{Zárógondolatok}

A fent bemutatott kísérletekkel, megfigyelésekkel, játékkal érdekesebbé, változatosabbá tehetők az online biológia órák. Ezek segítségével a tanulók motiváltabbak lesznek és a tapasztalatszerzésen alapuló aktív tanulási folyamat is megvalósul, ami hosszú távú tudást ad (Borić és Škugor, 2014). A bemutatott gyakorlatok a felfedeztetéses tanulásnak is teret adhatnak (v.ö.: Mező, 2021). A kísérletekhez, megfigyelésekhez, játékhoz minden alapanyag, hozzávaló megtalálható a tanulók otthonában, így könnyedén kipróbálhatják ezeket. Próbáltunk részletes leírással, útmutatással szolgálni, hogy könnyen értelmezhetők legyenek a feladatok és biztos legyen a sikerélmény. A kísérletek, megfi- gyelések és a játék is teljesen biztonságos és veszélytelen, így a tanulók egyedül szülői segítség nélkül is elvégezhetik. Munkánk fő célkitűzése az volt, hogy a pedagógusoknak segítséget nyújtsunk, ötletek adjunk a digitális biológia órák érdekesebbé tételéhez. Reméljük ez sikerült!

\section{Irodalom}

Borić, E. \& Škugor, A. (2014). Achieving students' competencies through research-based outdoor science teaching. Croational Journal of Education,16(1), 149-164.

Borsos, É. (2018). The gamification of elementary school biology: a case study on increasing understanding of plants, Journal of Biological Education, 53(5), 492-505, doi: $\underline{10.1080 / 00219266.2018 .1501407}$

Czékus, G. (2005): A természetismeret tanitás módszertana. MM print Nyomda, Szabadka, Szerbia.

Czékus, G., Major, L., Horák, R. (2013): A környezetünk és a környezetismeret módszertana. Grafoprodukt, Szabadka, Szerbia.

Kriska, Gy. \& Karkus, Zs. (2015). A biológia tanitásának elmélete és gyakorlata. ELTE Eötvös Kiadó, Budapest, Magyarország.

Mező F. (2021): Felfedeztetéses tanulást segítő gyakorlatok az OxIPO-modell alapján. OxIPO - interdiszciplináris tudományos folyóirat, 2021/3, 83-97. doi: $\underline{10.35405 / O X I P O .2021 .3 .83}$

Ördög, V. \& Molnár, Z. (2011). Növényélettan. Debreceni Egyetem, Nyugat - 
Magyarországi Egyetem, Pannon fejlesztése". Kaposvári Egyetem.

Egyetem, Debrecen, Magyarország. Letöltés: 2021.10.10. Web:

Pedryc, A. (2014). A genetika és a növény- $\quad \underline{\text { http://janus.ttk.pte.hu/tamop/kaposv }}$ nemesités alapjai. Budapesti Corvinus ari_anyag/voros_peter/index.html

Egyetem Genetikai és Növényne- (megtekintés: 2021.4.14.).

mesítés Tanszék, Budapest, Magyar- Wagner, G. (2008). Botanical Knowledge ország. of a Group of College Students in

Turcsányi, G. \& Turcsányiné Siller, I. South Carolina, U.S.A. Ethnobotany (2005). Növénytan. Digitális Tankönyvtár. Letöltés: 2021. 10.10. Web: https://regi.tankonyvtar.hu/hu/tartal om/tkt/novenytannovenytan/index.html Research and Applications, 6, 443-458.

Wandersee, J. \& Schlusser, E. (2001). Toward a theory of plant blindness. Plant Science Bulletin, 17(1), 2-9.

Vörös, P. (2011). Oktatástechnológia és informatika agrár-mérnöktanár szakos ballgatók számára. „A kompetenciaalapú pedagógusképzés regionális szervezeti, tartalmi és módszertani 